\title{
PENENTUAN KAPASITAS ADSORPSI SELULOSA TERHADAP RHODAMIN B DALAM SISTEM DINAMIS
}

\author{
Asnawati Asnawati *, Resty Rukmi Kharismaningrum, Novita Andarini \\ Jurusan Kimia, FMIPA \\ Universitas Jember \\ "email: asnawati.fmipa@unej.ac.id
}

Received 6 Pebuari 2017

Accepted 3 Mei 2017

\begin{abstract}
Abstrak
Penelitian ini bertujuan untuk menentukan kapasitas adsorpsi selulosa terhadap rhodamin B dengan optimasi massa adsorben dan $\mathrm{pH}$ larutan. Kapasitas adsorpsi ditentukan dengan sistem dinamis dengan kecepatan $0,08 \mathrm{~mL} /$ menit melalui kolom berdiameter internal $8 \mathrm{~mm}$ yang mengandung selulosa. Kapasitas adsorpsi selulosa ditentukan dengan menggunakan persamaan Thomas. Kurva breakthrough digunakan untuk mengetahui keefektifan kolom dalam mengadsorpsi. Massa adsorben divariasi sebesar 0,$1 ; 0,2$; dan 0,3 gram serta $\mathrm{pH}$ larutan influen divariasi pada $\mathrm{pH}$ 5, 6 dan 7. Massa adsorben dan $\mathrm{pH}$ larutan influen dengan kapasitas adsorpsi paling optimum adalah massa 0,3 gram dan $\mathrm{pH}$ 7. Kapasitas adsorpsi selulosa terhadap rhodamin B sebesar $5,94 \mathrm{mg} / \mathrm{g}$.
\end{abstract}

Kata kunci: Adsorpsi, rhodamine B, selulosa, sistem dinamis.

\begin{abstract}
This aim of this research is to determine the adsorption capacity of the cellulose toward rhodamine $\mathrm{B}$ by optimizing the amount of adsorbent and the $\mathrm{pH}$ of the solution. The adsorption capacity of cellulose is determined in a dynamic method with a flow rate of 0.08 $\mathrm{mL} /$ minutes through a column ( $8 \mathrm{~mm}$ id) containing cellulose. Thomas equation is used to calculate the adsorption capacity of cellulose. The effectiveness of column adsorbent is derived from breakthrough curve. The amount of adsorbent was set $0.1 ; 0.2$ and 0.3 gram and $\mathrm{pH}$ of the solutions are 5,6 and 7. The highest adsorption capacity is achieved with the mass of adsorbent of 0.3 gram and $\mathrm{pH}$ of solution of 7 . Adsorption capacity of cellulose toward rhodamine B is $5.94 \mathrm{mg} / \mathrm{g}$.
\end{abstract}

Keywords: Adsorption, rhodamine B, cellulose, dynamic system

\section{Pendahuluan}

Zat warna sintetik umumnya dibuat dari senyawa azo dan turunannya dari gugus benzen. Gugus benzen sangat sulit didegradasi dan membutuhkan waktu degradasi yang lama (Mamoto et al, 2013). Metode yang paling banyak digunakan untuk pengolahan limbah zat warna adalah adsorpsi (Widjanarko et al, 2006). Adsorben yang paling banyak digunakan saat ini adalah adsorben yang berasal dari bahan alam. Beberapa adsorben bahan alami yang digunakan yaitu: tongkol jagung (Munawaroh, 2012), kulit ari 
gandum (Suwarsa, 1997), dan serat daun nanas (Hastuti et al, 2012). Senyawa yang ada dalam bahan alami yang berperan dalam proses adsorpsi yaitu selulosa, lignin, dan hemiselulosa. Penelitian secara spesifik untuk mengetahui kapasitas setiap senyawa pada bahan alami dalam mengadsorpsi zat warna belum ditemukan, sehingga perlu dilakukan penelitian agar diketahui secara spesifik berapa kapasitas adsorpsi dari masing-masing senyawa tersebut. Kapasitas adsorpsi setiap senyawa yang terdapat pada bahan-bahan alami dipengaruhi oleh struktur masingmasing senyawa. Adsorben selulosa, lignin dan hemiselulosa memiliki monomer yang berbeda sehingga kemampuan untuk mengadsorpsi zat warna juga berbeda. Selulosa merupakan salah satu senyawa yang terdapat pada bahan alam dengan kandungan yang lebih banyak dibandingkan lignin dan hemiselulosa. Menurut (Cooney, 1998), selulosa mempunyai karakter hidrofilik serta mempunyai gugus alkohol primer dan sekunder yang keduanya mampu mengadakan reaksi dengan zat warna reaktif.

Secara umum terdapat banyak faktor yang mempengaruhi adsorpsi fisika dan kimia yaitu: suhu, sifat pelarut, area permukaan adsorben, struktur pori adsorben dan pH larutan (Hidayat, 2008). Kurniawan, 2010 menyatakan bahwa terdapat beberapa parameter khusus yang mempengaruhi proses adsorpsi dari senyawa organik, tergantung dari beberapa karakteristik senyawa organik tersebut, diantaranya: massa adsorben, struktur molekul, dan $\mathrm{pH}$ larutan influen. Parameter adsorpsi mempengaruhi besarnya kapasitas suatu adsorben dalam menyerap adsorbat. Kapasitas adsorpsi menyatakan banyaknya adsorbat yang mampu terakumulasi pada permukaan adsorben. Kapasitas adsorpsi yang maksimum dapat diperoleh setelah dilakukan optimasi parameter yang mempengaruhi adsorpsi (Kurniawan, 2010).
Metode adsorpsi yang umum digunakan adalah metode batch dan dinamis (Hadiwidodo, 2008). Metode batch untuk adsoprsi zat warna telah banyak diteliti yaitu: adsorpsi zat warna Congo Red dan Rhodamin B menggunakan serabut kelapa dan ampas tebu (Widjanarko et al, 2006) serta penggunaan kulit pisang dan jeruk untuk adsorpsi zat warna sintetik (Annadurai et $a l$, 2002), penggunaan limbah industri kertas (Thakur and Kaur, 2017)

Penelitian menggunakan metode dinamis yaitu: adsorpsi 2,4-dichlorophenol menggunakan biomassa Phanerochaete chrysosporium ( $\mathrm{Wu} \& \mathrm{Yu}, 2008)$ dan adsorpsi pewarna organik (Gribhi et al, 2011). Kelebihan metode dinamis adalah penggunaan aliran pada proses adsorpsinya. Sistem dinamis lebih menguntungkan karena proses ini mempunyai pendekatan yang lebih baik di lapangan karena sistem operasinya yang selalu mengontakkan larutan dengan adsorben sehingga permukaan adsorben dapat menyerap secara optimal sampai kondisi jenuhnya. Penelitian kapasitas adsorpsi pada metode dinamis menggunakan pendekatan persamaan Thomas. Persamaan Thomas menggambarkan penentuan kapasitas adsorpsi berdasarkan konsentrasi influen dan efluen, kecepatan aliran pada flow process, serta volume larutan yang dilewatkan pada kolom adsorben (Thomas, 1944). Berdasarkan uraian di atas maka dilakukan penelitian tentang kapasitas adsorpsi selulosa terhadap rhodamin B dalam sistem dinamis dengan memvariasikan beberapa parameter yang mempengaruhi adsorpsi. Penelitian ini bertujuan untuk mengetahui kapasitas adsorpsi selulosa terhadap Rhodamin B dengan optimasi massa adsorben dan $\mathrm{pH}$ larutan influen opitmum.

\section{Metode Penelitian Alat dan Bahan}


Bahan kimia yang diperlukan yaitu : asam oksalat $99.5-102.5 \%$ (ACS), natrium hidroksida $99.996 \%$ (Merck), asam asetat 99,7\% (Merck), kalium dihidrogen fosfat $\geq 99.0 \% \quad$ Redi-Dri ${ }^{\mathrm{TM}}$, natrium asetat anhydrous, $99.0 \%$ (ACS), rhodamin B $\geq 95 \%$ (Sigma-Aldrich) dan selulosa (Sigma-Aldrich) dan glasswol. Peralatan yang digunakan untuk analisa yaitu set alat infus dengan diameter dalam selang $5 \mathrm{~mm}$, kolom kaca (diameter dalam 0,8 cm; diameter luar $1 \mathrm{~cm}$; panjang $20 \mathrm{~cm}$ ) dan $752 \mathrm{~N}$ spectrophotometer lab equipment uv-vis new N, pH meter tipe EAI pH 2011 $\mathrm{CE}$, dan peralatan gelas

\section{Prosedur Penelitian \\ Preparasi Larutan rhodamine $B$.}

Larutan stock rhodamine B 100 ppm dibuat dengan melarutkan $100 \mathrm{mg}$ rhodamin B dengan akuades sampai volume larutan $1 \mathrm{~L}$. Pembuatan buffer asetat $\mathrm{pH} 5$ dan $\mathrm{pH} 6$ dilakukan dengan mencampurkan larutan $\mathrm{CH}_{3} \mathrm{COOH} 0,1 \mathrm{M}$ dan larutan $\mathrm{CH}_{3} \mathrm{COONa}$ 0,1 M. Pembuatan buffer fosfat $\mathrm{pH} 7$ dilakukan dengan cara mencampurkan larutan $\mathrm{NaOH} \mathrm{0,1} \mathrm{M} \mathrm{dan}$ larutan $\mathrm{KH}_{2} \mathrm{PO}_{4}$ 0,1 M. Larutan rhodamin B $10 \mathrm{ppm}$ dibuat dengan mengencerkan larutan rhodamin B 100 ppm dengan menggunakan larutan buffer $\mathrm{pH} 5, \mathrm{pH} 6$ dan $\mathrm{pH} 7$.

\section{Preparasi Kolom Kerja}

Kolom kerja disiapkan dengan menimbang sebanyak $0,1 \mathrm{~g} ; 0,2 \mathrm{~g}$ dan 0,3 g selulosa dimasukkan ke dalam kolom kerja. Kolom kerja dilapisi dengan glasswol pada bagian dasar kolom dan atas adsorben. Rancangan set desain kolom kerja dapat dilihat pada gambar 1 . Kolom kerja terdiri atas set alat infus dengan kran (pengatur laju alir) telah datur pada posisi tetap. Kabel infus dihubungkan dengan kolom kaca. Efluen yang keluar ditampung dengan menggunakan gelas beaker. Variasi $\mathrm{pH}$ influen menggunakan larutan buffer phospat dan buffer asetat pada $\mathrm{pH} 5$, 6 dan 7. Penentuan kapasitas adsorpsi menggunakan model pendekatan Thomas.
Kapasitas adsorpsi kolom $\mathrm{q}_{\mathrm{o}}$ dapat ditentukan dari plot Veff vs $\ln [(\mathrm{Co} / \mathrm{Ce})-1]$ pada laju alir tertentu. Nilai intersep grafik digunakan untuk menentukan nilai kapasitas adsorpsi sedangkan nilai gradient digunakan untuk menentukan nilai konstanta Thomas sesuai dengan persamaan linear dengan memasukkan semua nilai yang telah diketahui ke dalam persamaan tersebut.

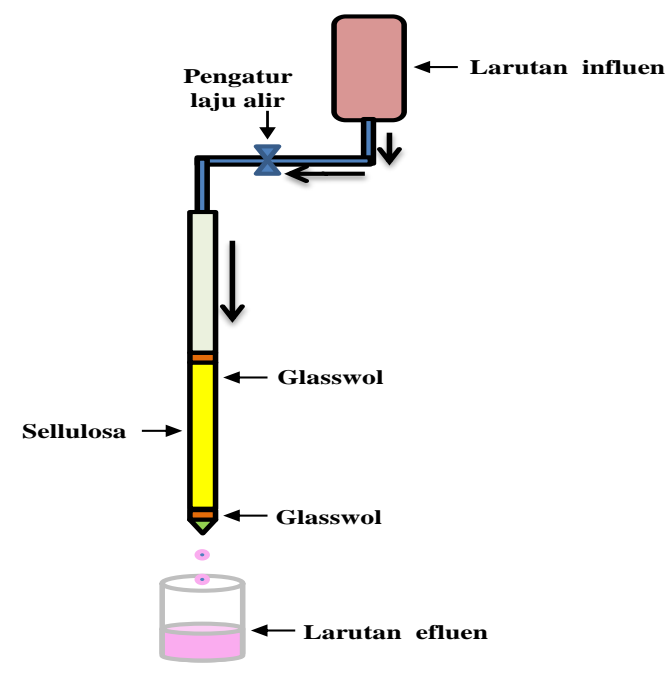

Gambar 1. Set desain kolom kerja

Penentuan parameter optimum dan kapasitas adsorpsinya

Analisis proses adsorpsi dilakukan dengan variasi massa diawali dengan memasukkan larutan rhodamin B 10 ppm dengan $\mathrm{pH} 7$ ke dalam kantong infus dan diatur kecepatan alir $0,08 \mathrm{~mL} /$ menit yang mengalir ke dalam kolom yang berisi selulosa dengan variasi massa $0,1 \mathrm{~g} ; 0,2 \mathrm{~g}$ dan $0,3 \mathrm{~g}$. Analit yang keluar ditampung setiap $50 \mathrm{~mL}$ dan diukur adsorbansi dengan spektrofotometer uv-vis dan dilakukan hingga kolom jenuh. Variasi $\mathrm{pH}$ analisis dilakukan dengan melewatkan larutan rhodamin $\mathrm{B}$ pH 5, pH 6 dan $\mathrm{pH} 7$ ke dalam kolom yang berisi selulosa dengan massa optimum dengan kecepatan alir sama dan dilakukan perlakuan yang sama seperti pada optimasi massa. Penentuan kapasitas optimum dilakukan dengan melewatkan larutan rhodamin B dengan pada $\mathrm{pH}$ dan massa optimum ke 
dalam kolom berisi selulosa dengan kecepatan alir yang sama dan dilakukan perlakuan yang sama seperti pada tahap optimasi.

Analisis data yang diperoleh untuk mendapatkan nilai kapasitas adsorpsi lignin terhadap rhodamin B dalam sistem dinamis menggunakan persamaan model Thomas (Persamaan 1). Dengan $\mathrm{C}_{\mathrm{o}}$, konsentrasi influen (mg/L), Ce, konsentrasi efluen (mg/L), KTh, konstanta laju Thomas (mL/menit.mg), qo, kapasitas adsorpsi (mg/g), Q, laju alir influen $(\mathrm{mL} / \mathrm{menit}), \mathrm{M}$, massa adsorben $(\mathrm{g}), \mathrm{V}_{\text {eff }}$, volume efluen (L). (Nwabanne \& Igbokwe, 2012)

$$
\ln \left(\frac{C_{o}}{C_{e}}-1\right)=\frac{K T h \cdot q_{o} \cdot M}{Q}-\frac{K T h \cdot C_{o}}{Q} V_{e f f}
$$

\section{Hasil dan Pembahasan}

\section{Massa Adsorben}

Penentuan massa adsorben selulosa dengan variasi $0,1 \mathrm{~g} ; 0,2 \mathrm{~g}$ dan $0,3 \mathrm{~g}$. rhodamin $\mathrm{B}$ dialirkan terus-menerus ke dalam kolom hingga adsorben selulosa berada pada titik jenuh. Titik jenuh memiliki arti bahwa adsorben sudah tidak mampu menyerap adsorbat lagi. Gambar 2(a) menunjukkan bahwa massa 0,3 gram adsorben dapat menyerap rhodamin B dengan kapasitas tertinggi yaitu sebanyak 400 mL. Nilai tersebut menunjukkan semakin banyak massa adsorben semakin banyaknya sisi aktif yang dapat mengikat adsorbat.

Grafik pada gambar 2(b) menggambarkan penjelasan kurva breakthrough dimana break point ditunjukkan pada rasio Ce/Co mendekati $5 \%$. Rasio Ce/Co yang telah melebihi $5 \%$ menunjukkan bahwa proses adsorpsi telah terjadi pada kolom. Berdasarkan gambar 2(b) menunjukkan bahwa titik break point pada massa 0,1 gram sebesar $64 \mathrm{~mL}$, massa 0,2 gram sebesar $32 \mathrm{~mL}$, dan massa 0,3 gram sebesar $6 \mathrm{~mL}$. Nilai exhaustion point pada massa adsorben 0,1 gram sebesar $256 \mathrm{~mL}$, pada massa 0,2 gram sebesar $301 \mathrm{~mL}$, dan massa 0,3 gram sebesar $366 \mathrm{~mL}$. Kurva breakthrough menunjukkan keadaan analit dalam suatu kolom.
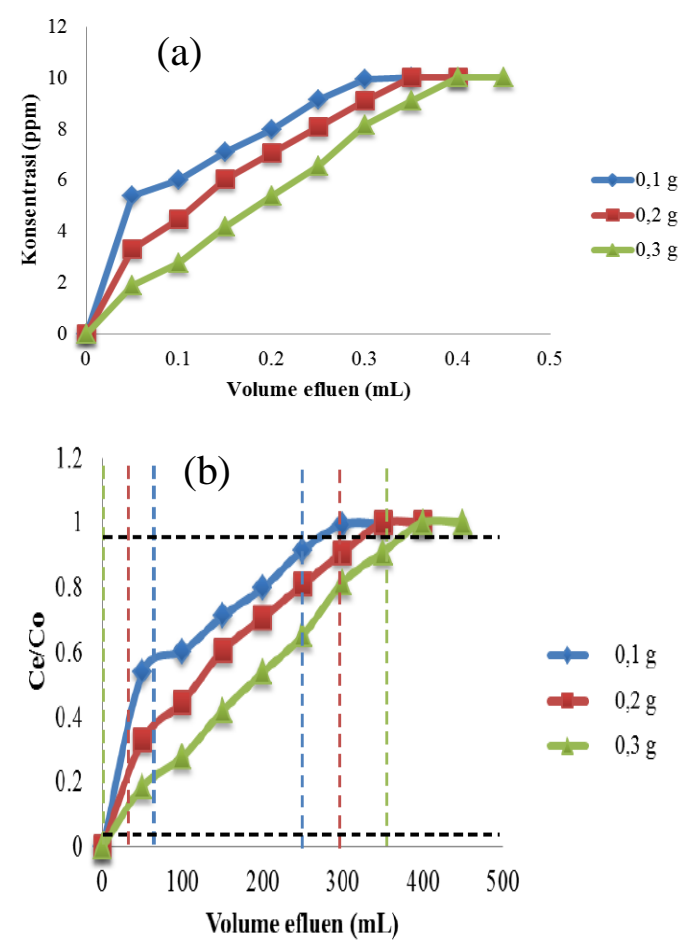

Gambar 2. (a) Kurva konsentrasi vs volume efluen, (b) kurva breakthrough variasi massa adsorben dan $\mathrm{pH}$ influen 7.

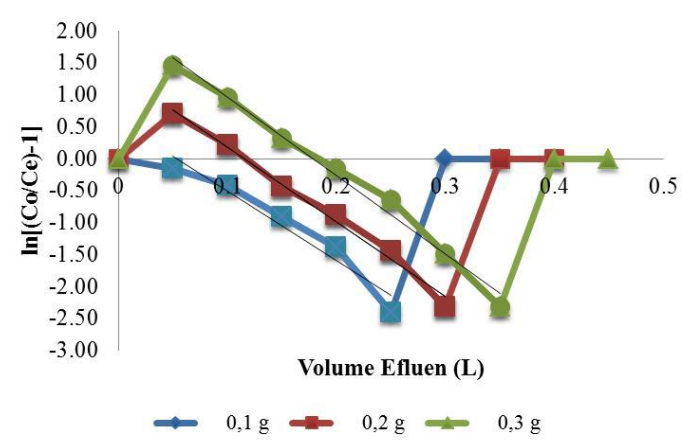

Gambar 3. Pengukuran kapasitas adsorpsi dengan persamaan Thomas pada variasi massa dan $\mathrm{pH}$ influen 7

Gambar 3 digunakan untuk perhitungan persamaan Thomas dimana hasil kapasitas adsorpsi kolom selulosa dengan massa 0,1 gram hingga 0,3 gram berturut-turut sebesar $5,36 \mathrm{mg} / \mathrm{g} ; 5,51 \mathrm{mg} / \mathrm{g}$; dan 5,72 $\mathrm{mg} / \mathrm{g}$. Penentuan massa optimum adsorben diperoleh dari nilai kapasitas adsorpsi yang paling maksimum pada variasi massa adsorben. Dengan demikian massa 
optimum adalah 0,3 gram karena memiliki kapasitas adsorpsi maksimum.

Nilai kapasitas adsorpsi paling tinggi dihasilkan dari kolom selulosa dengan massa 0,3 gram seperti pada Gambar 4 dimana kolom tersebut dapat menyerap $5,72 \mathrm{mg}$ rhodamin B tiap 1 gram selulosa dengan kecepatan alir $0,08 \mathrm{~mL} /$ menit. Kapasitas adsorpsi tersebut menunjukkan banyaknya rhodamin B yang mampu diadsorp selulosa. Kemampuan adsorpsi ditentukan oleh struktur suatu adsorben dan parameter adsorpsi lainnya. Massa adsorben yang tinggi memberi peluang bagi adsorbat untuk teradsorpsi pada adsorben sehingga kapasitas adsorpsi juga meningkat. Penelitian ini tidak menggunakan variasi massa di atas 0,3 gram karena kapasitas kolom yang digunakan pada penelitian ini hanya mampu menganalisis massa adsorben maksimal 0,3 g.

\section{Penentuan $\mathrm{pH}$ Influen rhodamine $B$}

Larutan rhodamine B 10 ppm yang telah dikondisikan dengan buffer $\mathrm{pH}$ 5, 6 dan 7 masing-masing dialirkan ke dalam kolom dengan massa adsorben 0,3 gram dengan kecepatan alir $0,08 \mathrm{~mL} /$ menit. Kapasitas adsorpsi selulosa maksimum pada variasi $\mathrm{pH} 5,6$, dan 7 merupakan $\mathrm{pH}$ adsorbat optimum. Kolom selulosa dengan variasi $\mathrm{pH}$ influen dapat menyerap Rhodamin B dengan volume pada $\mathrm{pH} 5$ hingga 7 berturut-turut sebesar 300, 350, dan $400 \mathrm{~mL}$. Nilai adsorbansi tertinggi diperoleh kolom dengan massa selulosa 0,3 gram pada $\mathrm{pH} 7$ karena pada kolom tersebut dapat menyerap influen dengan volume tertinggi. Nilai volume tertinggi ditunjukkan pada Gambar 5(a) yang menggambarkan bahwa volume influen tertinggi yang dapat diserap saat $\mathrm{pH}$ larutan Rhodamin B sebesar 7.
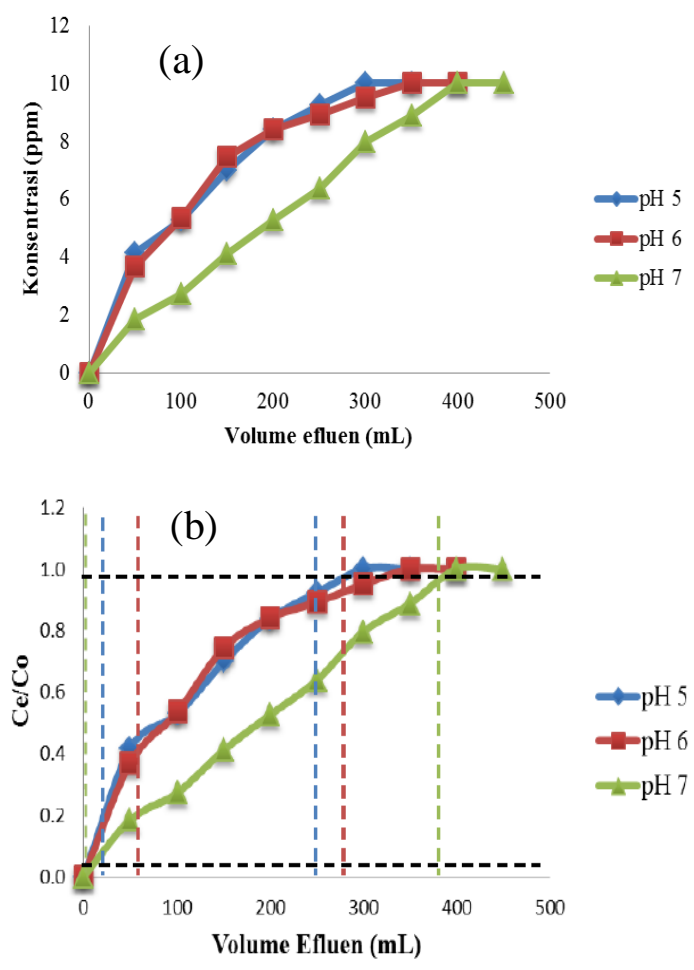

Gambar 4. (a) kurva konsentrasi vs volume efluen, (b) kurva breakthrough variasi $\mathrm{pH}$ influen dan adsorben $0,3 \mathrm{~g}$.

Kuva breakthrough (Gambar 4b) pada optimasi $\mathrm{pH}$ yang dilakukan menunjukkan rasio antara konsentrasi efluen dengan konsentrasi influen. Rasio $\mathrm{Ce} / \mathrm{Co}$ digunakan untuk mengetahui volume efektif yang dapat diserap adsorben dan volume maksimum kolom untuk menyerap rhodamin B. Nilai break point $\mathrm{pH}$ 5, 6, dan 7 berturut-turut sebesar $38 \mathrm{~mL}, 60 \mathrm{~mL}$, dan $7 \mathrm{~mL}$. Nilai exhaustion

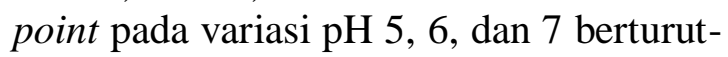
turut sebesar $253 \mathrm{~mL}, 286 \mathrm{~mL}$, dan 382 $\mathrm{mL}$. Banyaknya volume rhodamin yang diserap kolom pada break point hingga exhaustion point menunjukkan kemampuan kolom yang semakin baik. Kurva breakthrough yang memiliki kemampuan menyerap rhodamin B lebih banyak sebelum mencapai titik jenuh ditunjukkan pada kolom dengan massa 0,3 gram dan variasi $\mathrm{pH}$ larutan influen sebesar 7 . 


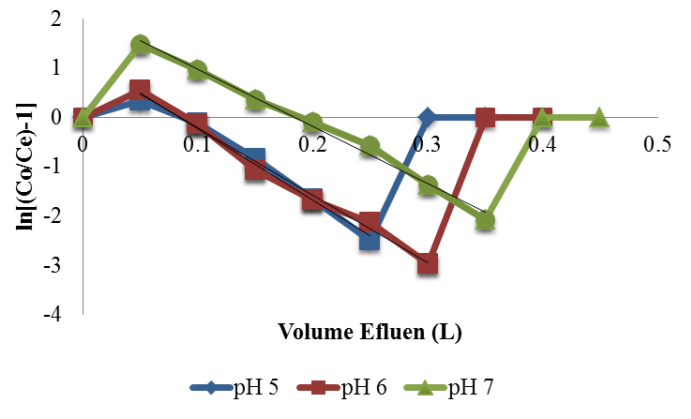

Gambar 5. Grafik pengukuran kapasitas adsorpsi melalui persamaan Thomas dengan variasi $\mathrm{pH}$ dan massa adsorben 0,3 $\mathrm{g}$

Kapasitas adsorbsi pada kolom selulosa dihitung melalui persamaan Thomas dari hasil plot antara volume efluen dengan persamaan $\ln [(\mathrm{Co} / \mathrm{Ce})-1$. Berdasarkan grafik yang diperoleh pada Gambar 6 didapatkan persamaan garis linear pada variasi $\mathrm{pH} 5,6$, dan 7 . Nilai kapasitas adsorbsi didapatkan dari besarnya nilai intersep dan nilai konstanta Thomas diperoleh dari nilai gradient pada persamaan tersebut.

Nilai kapasitas adsorpsi rhodamin B oleh selulosa pada variasi $\mathrm{pH} 5,6$ dan 7 berturut-turut sebesar 2,65 mg/g, 2,67 $\mathrm{mg} / \mathrm{g}$ dan $5,80 \mathrm{mg} / \mathrm{g}$. Berdasarkan data (Gambar 5) maka nilai kapasitas adsorpsi tertinggi saat $\mathrm{pH}$ influen 7 . Ketika $\mathrm{pH}$ influen asam kemungkinan ion $\mathrm{H}^{+}$pada larutan influen akan memutuskan gugus $\mathrm{OH}$ pada selulosa. Gugus $\mathrm{OH}$ pada selulosa yang berkurang akan menurunkan interaksi hidrogen antara ion rhodamin B dengan selulosa sehingga kapasitas adsorpsi selulosa terhadap rhodamin B juga berkurang.

\section{Kapasitas adsorpsi optimum selulosa}

Kapasitas adsorpsi optimum ditentukan setelah melakukan optimasi massa adsorben dan $\mathrm{pH}$ larutan influen. Massa optimum dari adsorben yang digunakan sebesar 0,3 gram dan $\mathrm{pH}$ larutan influen 7 . Volume larutan influen yang diserap selulosa sampai mengalami titik jenuh sebesar $400 \mathrm{~mL}$ (gambar 6). Berdasarkan hasil tersebut maka didapatkan kurva breakthrough untuk kapasitas adsorpsi selulosa optimum seperti pada gambar 6 Nilai break point pada kolom optimum sebesar $5 \mathrm{~mL}$ sedangkan nilai exhaustion point sebesar $370 \mathrm{~mL}$. Nilai tersebut menunjukkan bahwa kolom selulosa mampu bekerja mengikat $365 \mathrm{~mL}$ rhodamin B sebelum kolom tersebut mencapai titik jenuh.

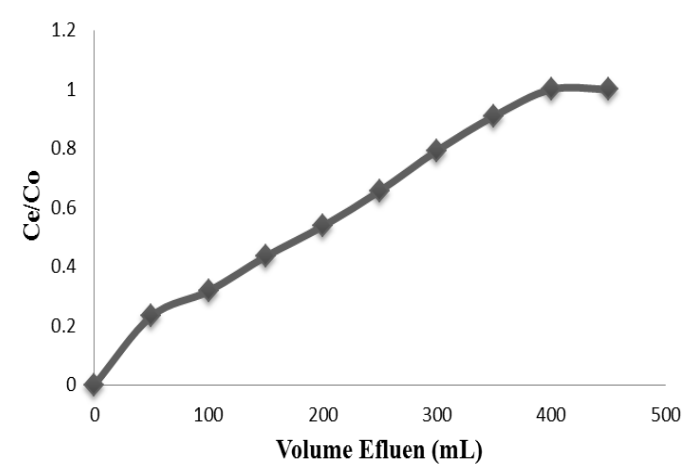

Gambar 6. Kurva breakthrough dengan massa adsorben $0,3 \mathrm{~g}$ dan $\mathrm{pH}$ influen 7

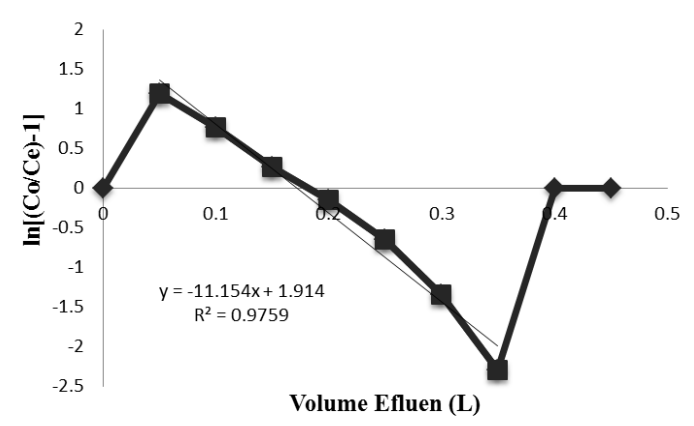

Gambar 7. Pengukuran kapasitas adsorpsi dengan persamaan Thomas pada massa adsorben $0,3 \mathrm{~g}$ dan $\mathrm{pH}$ influen 7

Gambar 7 menunjukkan plot untuk menentukan kapasitas adsorpsi selulosa dalam menyerap rhodamin B dimana dari grafik linier tersebut didapatkan persamaan $\mathrm{y}=-11,154 \mathrm{x}+1,914$.

Berdasarkan persamaan tersebut maka didapatkan nilai kapasitas adsorpsi Rhodamin B oleh selulosa sebesar 5,94 $\mathrm{mg} / \mathrm{g}$. Artinya setiap 1 gram selulosa mampu menyerap 5,94 mg rhodamin B dengan kecepatan alir 0,08 mL/menit. 


\section{Kesimpulan}

Berdasarkan hasil penelitian dapat disimpulkan bahwa kapasitas adsorpsi selulosa dalam mengadsorpsi rhodamin B yaitu sebesar $5,94 \mathrm{mg} / \mathrm{g}$ dengan massa selulosa optimum dalam kolom kaca (diameter dalam $0,8 \mathrm{~cm}$ ) sebesar 0,3 gram dan $\mathrm{pH}$ optimum larutan influen Rhodamin B adalah 7.

\section{Daftar Pustaka}

Annadurai, Gurusamy. Juang, Ruey-Shin. Lee, Duu-Jong. 2002, Use Of Cellulose-Based Wastes For Adsorptionof Dyes From Aqueous Solutions, J. Hazardous Materials, 263-274

Cooney, D.O. 1998, Adsorption Design For Wastewater Treatment, USA: Lewis Publishers

Hadiwidodo, M. 2008, Penggunaan Abu Sekam Padi sebagai Adsorben dalam Pengolahan Air Limbah yang Mengandung Logam $\mathrm{Cu}$, Jurnal Teknik, 29, 55-63

Hastuti, Sri. Mawahib, Syarif. Setyoningsih. 2012, Penggunaan Serat Daun Nanas Sebagai Adsorben Zat Warna Procion Red Mx 8b, Jurnal Kimia, Surakarta: Universitas Sebelas Maret

Hidayat, P. 2008, Teknologi Pemanfataan Serat Daun Nanas sebagai Alternatif Bahan Baku Tekstil, Jurnal Kimia, 13, 31-35

Kurniawan. 2010, The Use Of Rice Straw To Eliminate Waste Color Textile Industry Color Index Reactive Orange 84, Jurnal teknik sipil dan lingkungan Mamoto, Lidya Valda \& Citraningtyas, Fatimawali Gayatri. 2013, Analisis Rhodamin B Pada Lipstik Yang Beredar Di Pasar Kota Manado, Jurnal Kimia Farmasi, Manado: UNSRAT Manado

\section{Ucapan terima kasih}

Penulis mengucapkan terima kasih kepada Kepala Laboratorium Kimia Analitik Jurusan Kimia Fakultas Matematika dan Ilmu Pengetahuan Alam Universitas Jember yang telah memberikan ruang serta sarana dan prasarana dalam penelitian ini. Ucapan terima kasih juga disampaikan kepada pihak-pihak yang membantu penelitian ini.

Munawaroh, I. 2012, Pemanfaatan Bonggol Jagung Sebagai Adsorben Rhodamin B Dan Metanil Yellow, Skripsi kimia, Yogyakarta: UIN Sunan Kalijaga Yogyakarta

Nwabanne, J.T. and Igbokwe, P.K. 2012, Adsorption Performance of Packed Bed Column for the Removal of Lead (II) using Oil Palm Fibre, Int. J. App. Sci.Tech, 2, 106-115

Suwarsa, S. 1997, Penyerapan Zat Warna Tekstil BR Red HE 7B Oleh Jerami Padi+), Jurnal Kimia. Bandung, ITB

Thakur, A and Kaur, H. 2017, Response surface optimization of Rhodamine B dye removal using paper industry waste as adsorbent, Int J Ind Chem,

Thomas, Henry. 1944, Heterogeneous Ion Exchange in Flowing System, Int J. Chem, 66: 1664-1666

Widjanarko, Widiantoro \& Soetaredjo. 2006, Kinetika Adsorben Zat Warna Congo Red dan Rhodamin B dengan Menggunakan Serabut Kelapa dan Tebu, Jurnal Tehnik Kimia, Universitas Katolik Widya Mandala Surabaya.

Wu, Juan. Yu, Han-Qing. 2008, Biosorption Of 2,4-Dichlorophenol From Aqueous Solutions By Immobilized Phanerochaete Chrysosporium Biomass In A FixedBed Column, J. chem Engineering, 138, 128-135 